\title{
KARAKTER FENOTIPE DAN GENOTIPE IKAN KERAPU HIBRIDA CANTIK (Epinephelus fuscoguttatus $\mathrm{x}$ E. polyphekadion)
}

\author{
Ahmad Muzaki"\#, Sari Budi Moria Sembiring"), Ida Komang Wardana", Haryanti", dan Ketut Sugama") \\ ") Balai Besar Penelitian dan Pengembangan Budidaya Laut \\ ") Pusat Penelitian dan Pengembangan Perikanan
}

\begin{abstract}
ABSTRAK
Pengamatan fenotipe dan genotipe ikan kerapu hibrida "cantik" yang merupakan hasil persilangan antara induk betina kerapu macan (Epinephelus fuscoguttatus) dengan induk jantan kerapu batik (Epinephelus polyphekadion) telah dilakukan. Tujuan penelitian ini adalah untuk mengevaluasi karakteristik fenotipe dan genotipe ikan kerapu hibrida cantik, sehingga dapat diketahui keunggulannya dalam rangka mendukung pengembangan marikultur. Penelitian ini meliputi tahapan persilangan buatan antara induk ikan kerapu macan betina dan kerapu batik jantan, pemeliharaan larva ikan kerapu hibrida cantik, dan kerapu nonhibrida (ikan kerapu batik dan macan), dan pemeliharaan benih dari masing-masing larva yang dihasilkan secara komunal maupun terpisah. Analisis genotipe dilakukan menggunakan dua alel penanda mikrosatelit terhadap benih ikan kerapu hibrida cantik dan non-hibrida. Hasil penelitian menunjukkan bahwa ikan kerapu hibrida cantik mempunyai pertumbuhan dan sintasan yang lebih baik dibandingkan dengan ikan kerapu macan dan batik. Berdasarkan karakter morfometrik dan meristik, ikan kerapu hibrida cantik cenderung memiliki kesamaan dengan ikan kerapu macan. Heterozigositas ikan kerapu hibrida cantik $(0,556-0,600)$ lebih baik dibandingkan dengan ikan kerapu macan $(0,000-0,556)$ dan batik $(0,200-0,600)$.
\end{abstract}

KATA KUNCI: fenotipe; genotipe; kerapu cantik; persilangan; Epinephelus fuscoguttatus; Epinephelus polyphekadion

ABSTRACT: $\quad$ Phenotype and genotype characters of cantik hybrid grouper (Epinephelus fuscoguttatus female $\mathrm{x}$ Epinephelus polyphekadion male). By: Ahmad Muzaki, Sari Budi Moria Sembiring, Ida Komang Wardana, Haryanti, dan Ketut Sugama

Observation on phenotype and genotype of "cantik" hybrid grouper which was derived by crossbreeding between tiger grouper (E. fuscoguttatus) female and camouflage grouper (E. polyphekadion) male has been performed. The purpose of this study was to determine the phenotype and genotype characteristics of a cantik hybrid grouper that can be known its advantage in order to support the mariculture development. The activity of the study included cross breeding between tiger grouper female and camouflage grouper male, larvae and fry rearing of hybrid grouper and non-hybrid grouper (camouflage and tiger grouper) and genotype analysis using two alleles of microsatellite marker on hybrid grouper and non-hybrid grouper. The results showed that cantik hibryd grouper has better growth and survival than that of tiger grouper and camouflage grouper. Based on morphometric and meristic characters, cantik hybrid grouper tended similar with tiger grouper. Heterozygosity values of hybrid grouper (0.556 to 0.600) was better tiger grouper (0.000 to 0.556) and camouflage grouper (0.200 to 0.600).

KEYWORDS: phenotype; genotype; cantik hybrid grouper; Epinephelus polyphekadion; Epinephelus fuscoguttattus

\# Korespondensi: Balai Besar Penelitian dan Pengembangan

Budidaya Laut. Jl. Br. Gondol Kec. Gerokgak Kab. Buleleng,

Kotak Pos 140, Singaraja, Bali 81101, Indonesia.

Tel.: + (0362) 92272; 92271

E-mail: gondolisme@yahoo.com 


\section{PENDAHULUAN}

Teknologi perbenihan dan pembesaran ikan kerapu telah berkembang di masyarakat. Sejak beberapa tahun terakhir terjadi penurunan permintaan terhadap komoditas ikan kerapu terutama ikan kerapu bebek dan ikan kerapu macan, sehingga diperlukan spesies alternatif ikan kerapu yang dapat diterima pasar. Bukan suatu hal yang mudah untuk mendapatkan ikan kerapu yang benar-benar baru dan belum pernah dibudidayakan, karena hal ini memerlukan proses yang panjang dan waktu lama, serta memerlukan biaya besar. Salah satu upaya yang dilakukan adalah dengan hibridisasi atau persilangan antara ikan kerapu yang permintaan pasarnya tinggi namun sulit untuk dibudidayakan dengan ikan kerapu yang sudah dapat dibudidayakan namun permintaan pasarnya rendah. Harapannya adalah dari hasil persilangan tersebut dapat dibudidayakan dengan mudah dan diterima oleh pasar.

Hibridisasi telah dilakukan pada berbagai spesies ikan dengan tujuan untuk meningkatkan laju pertumbuhan, memanipulasi rasio jenis kelamin, menghasilkan ikan yang steril, meningkatkan kualitas daging, perbaikan ketahanan terhadap penyakit, toleransi terhadap lingkungan, dan untuk berbagai sifat lain supaya lebih menguntungkan (Bartley et al., 2001). Identifikasi hibrida yang tepat yang memiliki pertumbuhan dan perkembangan awal yang baik dalam media budidaya merupakan salah satu tujuan kajian genetika sekarang dan masa depan terutama untuk genus Ephinephelus (Glamuzina et al., 2001).

Kajian hibridisasi pada ikan kerapu yang telah dilakukan di antaranya perkawinan silang ikan kerapu Epinephelus marginatus dengan E. aeneus (Glamuzina et al., 1999), hibridisasi ikan kerapu E. costae x E. marginatus (Glamuzina et al., 2001), hibridisasi ikan kerapu E. coioides x E. lanceolatus (Chu et al., 2010; Kiriyakit et al., 2011), dan hibridisasi ikan kerapu Plectropomus leopardus x P. maculatus (Frisch \& Hobbs, 2007).
Pada penelitian ini dilakukan persilangan antara ikan betina kerapu macan (E. fuscoguttatus) dengan jantan kerapu batik (E. polyphekadion). Hal ini berkaitan dengan kondisi yang ada bahwa ikan kerapu macan merupakan kerapu yang teknologi pembenihan dan pembesarannya telah dikuasai namun permintaan pasarnya menurun, dan telur yang dihasilkan cukup banyak. Sementara itu, teknologi pembenihan ikan kerapu batik masih sulit dan induknya masih cukup banyak tersedia dengan produktivitas sperma yang relatif tinggi. Hasil persilangan ikan betina kerapu macan dengan jantan kerapu batik selanjutnya disebut kerapu cantik yang merupakan singkatan dari macan batik. Penelitian ini bertujuan untuk mengevaluasi karakter fenotipe dan genotipe benih ikan kerapu hibrida cantik sehingga dapat diketahui keunggulan dari ikan kerapu tersebut dalam rangka mendukung pengembangan marikultur.

\section{BAHAN DAN METODE}

Penelitian dilakukan di Balai Besar Penelitian dan Pengembangan Budidaya Laut Gondol, Bali. Penelitian ini meliputi tiga tahapan kegiatan, yaitu:

\section{Persilangan Induk Betina Kerapu Macan dengan Jantan Kerapu Batik dan Pemeliharaan Larva Hasil Persilangannya (Disebut Kerapu Cantik) dan Larva dari Hasil Pemijahan Ikan Kerapu yang Non-Hibrida (Batik dan Macan)}

Kegiatan ini diawali dengan mencampurkan sperma ikan kerapu batik dengan telur kerapu macan untuk menghasilkan larva ikan kerapu hibrida cantik. Induk yang digunakan sebanyak empat ekor yaitu induk jantan dan betina kerapu batik, serta induk jantan dan betina kerapu macan masing-masing satu ekor. Ukuran bobot dan panjang induk-induk kerapu batik dan kerapu macan yang digunakan dalam penelitian ini tertera pada Tabel 1 .

Tabel 1. Panjang dan bobot induk ikan kerapu yang digunakan untuk menghasilkan larva hibrida dan non-hibrida

Table 1. Total length and body weight of grouper broodstocks that used to produce of hybrid and non-hybrid larvae

\begin{tabular}{lcc}
\hline \multicolumn{1}{c}{$\begin{array}{c}\text { Induk } \\
\text { Broodstock }\end{array}$} & $\begin{array}{c}\text { Panjang } \\
\text { Body length } \mathbf{( \mathbf { c m } )}\end{array}$ & $\begin{array}{c}\text { Bobot } \\
\text { Body weight } \mathbf{( k g )}\end{array}$ \\
\hline Kerapu batik jantan (Male of camouflage grouper) & 55 & 4.0 \\
Kerapu batik betina (Female of camouflage grouper) & 50 & 2.5 \\
Kerapu macan jantan (Male of tiger grouper) & 85 & 10.0 \\
Kerapu macan betina (Female of tiger grouper) & 65 & 8.0 \\
\hline
\end{tabular}


Macan

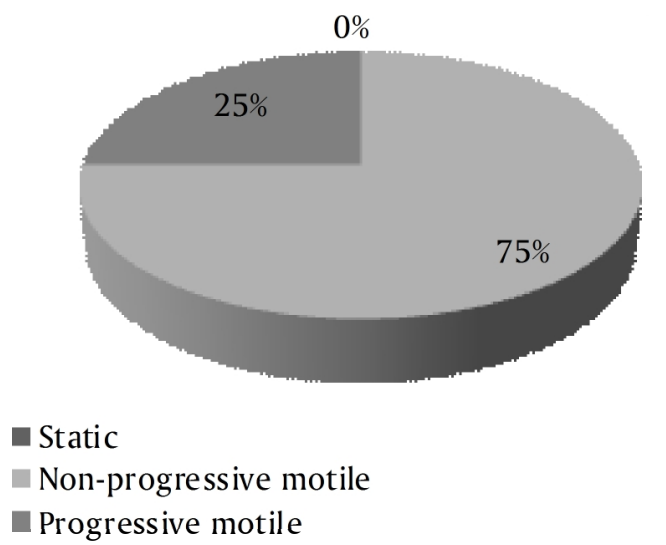

Batik

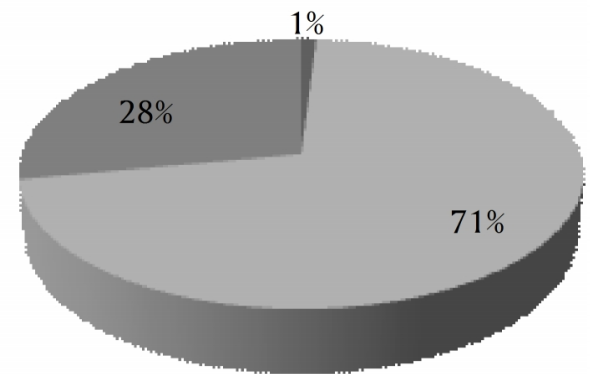

- Static

Non-progressive motile

- Progressive motile

Gambar 1. Tingkat motilitas sperma ikan kerapu macan dan batik

Figure 1. Spermatozoa motility levels of tiger and camouflage groupers

Tingkat motilitas sperma induk jantan yang digunakan dalam penelitian ini ditunjukkan pada Gambar 1. Motilitas sperma ikan kerapu diamati menggunakan Computer Assisted Sperm Anlysis dengan software Sperm Class Analyzer. Static menunjukkan sperma tidak bergerak, non progressive motile menunjukkan pergerakan sperma hanya di tempat sedangkan progressive motile menunjukkan sperma aktif bergerak (Kime et al., 2001).

Dari Gambar 1 diketahui bahwa tingkat motilitas sperma kerapu batik lebih baik dibandingkan dengan kerapu macan. Pengamatan motilitas dilakukan sesaat setelah proses stripping induk jantan dan selanjutnya disimpan pada suhu dingin $\left(-4^{\circ} \mathrm{C}\right)$ hingga digunakan pada saat pemijahan buatan yang dilakukan pada malam harinya saat bulan gelap.

Larva hasil persilangan kemudian dipelihara hingga mencapai stadia yuwana. Tahapan pemeliharaan larva mengikuti panduan yang telah ada (Sugama et al., 2012). Selain pemeliharaan larva ikan kerapu hibrida, juga dilakukan pemeliharaan larva ikan non-hibrida, masing-masing dari kerapu macan dan kerapu batik sebagai pembanding.

Penebaran telur ikan kerapu adalah 100.000 butir/ bak volume $6 \mathrm{~m}^{3}$. Sebanyak 30 butir telur dari masingmasing jenis kerapu diukur diameter dan butir minyaknya. Pakan awal larva setelah mulut terbuka yaitu pada umur tiga hari diberikan rotifer dengan kepadatan awal 5-6 ind./mL. Rotifer diberikan dua kali sehari pada pagi dan sore dan jumlah pemberian disesuaikan dengan sisa rotifer dalam tangki pemeliharaan. Setiap hari jumlah rotifer di bak larva dihitung, jika rotifer berkurang dari kepadatan tersebut, maka perlu ditambahkan hingga kepadatan rotifer di dalam bak tetap. Setelah umur larva delapan hari hingga umur 25 hari, pemberian rotifer ditingkatkan menjadi 10-15 ind./mL. Penambahan Nannochloropsis sp. ke dalam media pemeliharaan larva mulai umur dua hari sampai 25 hari, selain sebagai green water juga merupakan pakan alami untuk rotifer.

Pakan buatan berupa mikropelet mulai diberikan setelah larva berumur 6-8 hari. Ukuran pelet disesuaikan dengan ukuran mulut larva. Pakan buatan diberikan 4-6 kali sehari. Naupli Artemia mulai diberikan setelah larva berumur 17 hari hingga larva berumur 35 hari. Jumlah Artemia yang diberikan disesuaikan dengan perkiraan jumlah larva dan diberikan dua kali sehari (pagi dan sore). Pola pemberian pakan, pergantian air, dan pengelolaan lainnya dapat dilihat pada Tabel 2.

Peubah biologi yang diamati adalah perkembangan morfologi larva (panjang total, tinggi badan, diameter mata, panjang sirip punggung, panjang sirip anal, panjang duri sirip punggung, panjang duri sirip perut), pertumbuhan, dan sintasan larva. Pengamatan perkembangan morfologi dan pertumbuhan larva dilakukan pada 10 ekor larva masing-masing jenis kerapu. Dari data morfologi larva kemudian dibandingkan dengan panjang total larva dan selanjutnya dilakukan analisis secara deskriptif dan uji korelasi menggunakan software Microsoft Excel 2007 terhadap data tersebut.

\section{Pemeliharaan Benih Kerapu Hibrida Cantik dan Benih Kerapu Non-Hibrida (Batik dan Macan) Secara Komunal}

Benih ikan kerapu hibrida cantik, dan non-hibrida (macan dan batik) dengan umur yang sama dan ukuran relatif seragam, dipelihara secara komunal yaitu dalam 
Tabel 2. Pola pemberian pakan dan pergantian air pemeliharaan larva ikan kerapu cantik, macan dan batik

Table 2. Feeding and water exchange for larvae rearing of hybrid cantik, between tiger grouper, and camouflage grouper

\begin{tabular}{|c|c|}
\hline \multirow{2}{*}{ Pakan (Feed) } & Hari setelah menetas (Day after hatched) \\
\hline & $\begin{array}{lllllllllllll}1 & 2 & 3 & 5 & 8 & 10 & 12 & 15 & 20 & 25 & 30 & 35 & 40\end{array}$ \\
\hline Nannochloropsis sp. & --------- \\
\hline Rotifer & ------- \\
\hline Naupli Artemia & \\
\hline Pakan buatan (Artificial feed) & ---- \\
\hline Minyak ikan (Fish oil) & 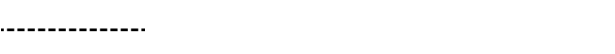 \\
\hline Pergantian air (Water changes) & $10 \%$-----------20\% ------50\% ---- \\
\hline Penyifonan & ----- \\
\hline
\end{tabular}

satu bak pemeliharaan, sedangkan sebagai pembanding dilakukan pemeliharaan ikan kerapu hibrida cantik, macan, dan batik masing-masing dipelihara dalam bak yang berbeda. Kepadatan awal benih ikan kerapu yang dipelihara secara komunal sebanyak 25 ekor untuk tiap jenis ikan (benih hibrida cantik, non-hibrid macan dan batik), dan masingmasing 75 ekor untuk tiap jenis benih ikan yang dipelihara secara terpisah. Pakan yang digunakan berupa ikan segar yang diberikan secara at satiation dengan frekuensi dua kali sehari (pagi dan sore hari).

Pengamatan peubah biologi meliputi pertumbuhan setiap bulan, sedangkan sintasan, karakter meristik, dan morfologi ikan kerapu cantik, macan, dan batik dilakukan pada akhir penelitian. Pengamatan karakter morfologi meliputi jumlah jari-jari keras dan jari-jari lemah pada setiap sirip, panjang total (PT), panjang standar (PS), diameter mata (DM), tinggi badan (TB), panjang kepala (PK), panjang sirip dorsal (PD), tinggi sirip dorsal (TD), panjang sirip pektoral (PP), tinggi sirip pektoral (TP), panjang sirip anal (PA), tinggi sirip anal (TA), tinggi ventral (TV), tinggi batang ekor (TBE), tinggi sirip kaudal (TC), dan lebar badan (LB). Data karakter morfologi yang diperoleh kemudian dibandingkan dengan panjang total dan selanjutnya dilakukan analisis secara deskriptif dan uji korelasi menggunakan software Microsoft Excel 2007 terhadap data tersebut.

\section{Analisis Genotipe Benih Ikan Kerapu Hibrida Cantik, Kerapu Non-Hibrida}

Analisis genotipe ikan kerapu hibrida, dan kerapu non-hibrida dilakukan dengan menggunakan dua lokus penanda mikrosatelit (simpel sequence repeats/SSR). Sampel ikan yang dianalisis adalah induk jantan kerapu batik dan betina kerapu macan masing-masing satu ekor dan benih kerapu macan, cantik, dan batik masingmasing lima ekor. Ekstraksi DNA dari sampel sirip dilakukan menggunakan DNEasy (DNA kit extraction) dari Qiagen. Protokol mengikuti manual yang ada, yaitu menggunakan spin column method. Proses amplifikasi PCR untuk penanda mikrosatelit membutuhkan volume reaksi sebesar $25 \mathrm{il}$, yang mengandung $10 \mathrm{x}$ bufer, dNTPs; Taq polymerase, primer EM-07 dan EM-08 (10 $\mathrm{mM}$ ) dengan menggunakan forward pada posisi 5' yang dilabel sebagai probe FAM dan HEX, hanya primer forward yang dilabel. Separasi elektroforesis fragmen DNA mikrosatelit selain menggunakan agarose gel dengan konsentrasi $1,5 \%$ pada $1 \mathrm{x}$ TBE, juga dengan mesin sequencer (ABI 3100 Aviant Genetic Analyzer sequencer) di $1^{\text {st }}$ Base laboratorium - Singapura. Hasil separasi kemudian diolah menggunakan Microsoft Excel dan dianalisis menggunakan software CERVUS 2.3.

\section{HASIL DAN BAHASAN}

\section{Hasil}

Persilangan induk betina kerapu macan dengan jantan kerapu batik dan pemeliharaan larva kerapu hibrid (cantik) dan larva ikan kerapu non-hibrid (batik dan macan).

Pemijahan buatan dilakukan untuk semua jenis kerapu yang diamati baik yang dikawin-silangkan untuk menghasilkan benih cantik maupun yang tidak. Persilangan secara resiprok antara betina kerapu batik dengan jantan kerapu macan juga dilakukan, namun pemeliharaan larvanya cukup sulit sehingga tidak berhasil mendapatkan benihnya. Kualitas telur hasil pemijahan buatan ditunjukkan pada Gambar 2 .

Dari Gambar 2 terlihat bahwa diameter telur ikan kerapu macan lebih besar $(856 \mu \mathrm{m})$ dibandingkan telur kerapu batik $(791 \mu \mathrm{m})$ dan sedikit lebih kecil 


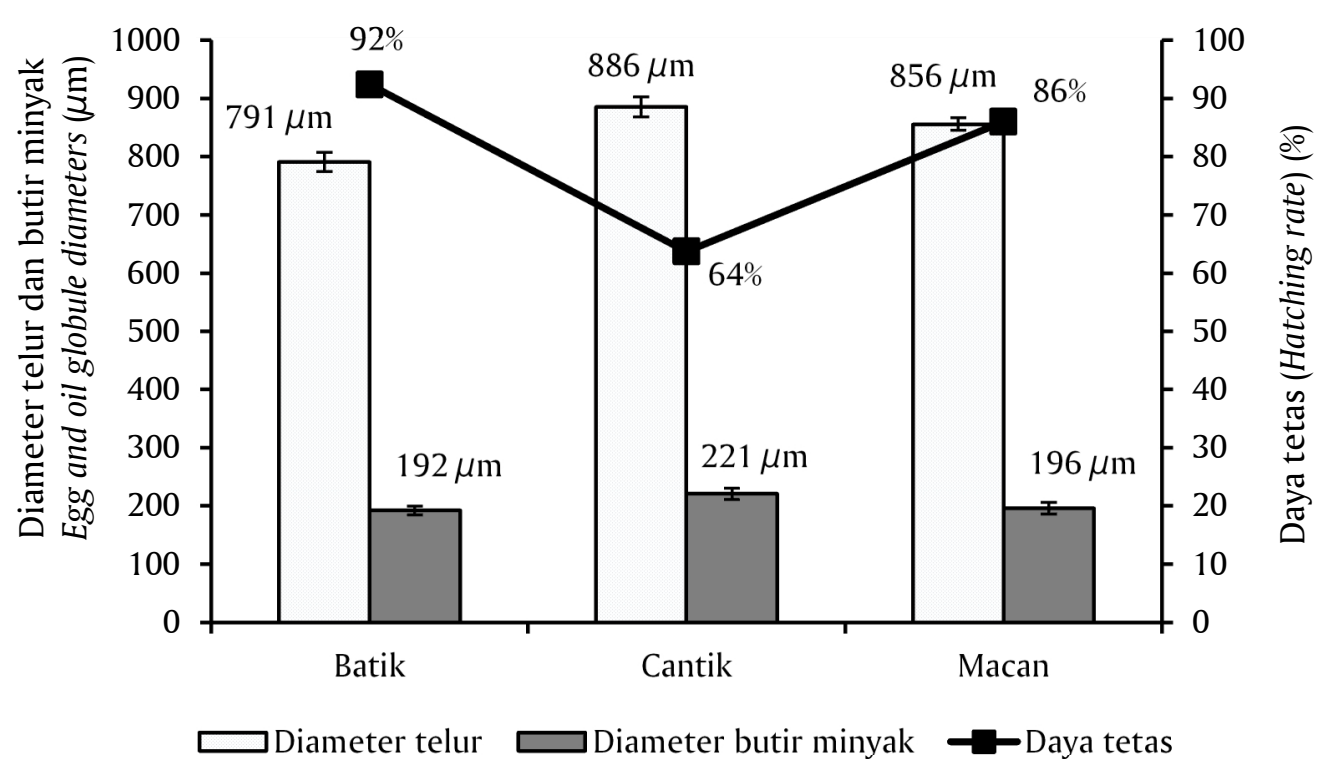

Gambar 2. Diameter telur, butir minyak, dan daya tetas telur ikan kerapu hibrida (cantik), dan non-hibrida ikan kerapu macan dan kerapu batik

Figure 2. Egg and oil globule diameters of hybrid cantik grouper, tiger grouper and camouflage grouper

dibandingkan telur kerapu cantik $(886 \mu \mathrm{m})$. Dari hasil pemijahan buatan yang dilakukan, daya tetas tertinggi diperoleh pada telur ikan kerapu macan $(92,37 \%)$; kemudian telur ikan kerapu batik $(86,00 \%)$ dan terendah pada hibrida untuk menghasilkan larva cantik $(63,70 \%)$.
Pola pertumbuhan larva ikan kerapu hibrida cantik, kerapu macan, dan kerapu batik yang dipelihara pada bak yang berbeda ditunjukkan pada Gambar 3. Larva ikan kerapu hibrida cantik memiliki pertumbuhan panjang yang lebih baik dibandingkan dengan ikan kerapu batik dan macan. Panjang total larva kerapu

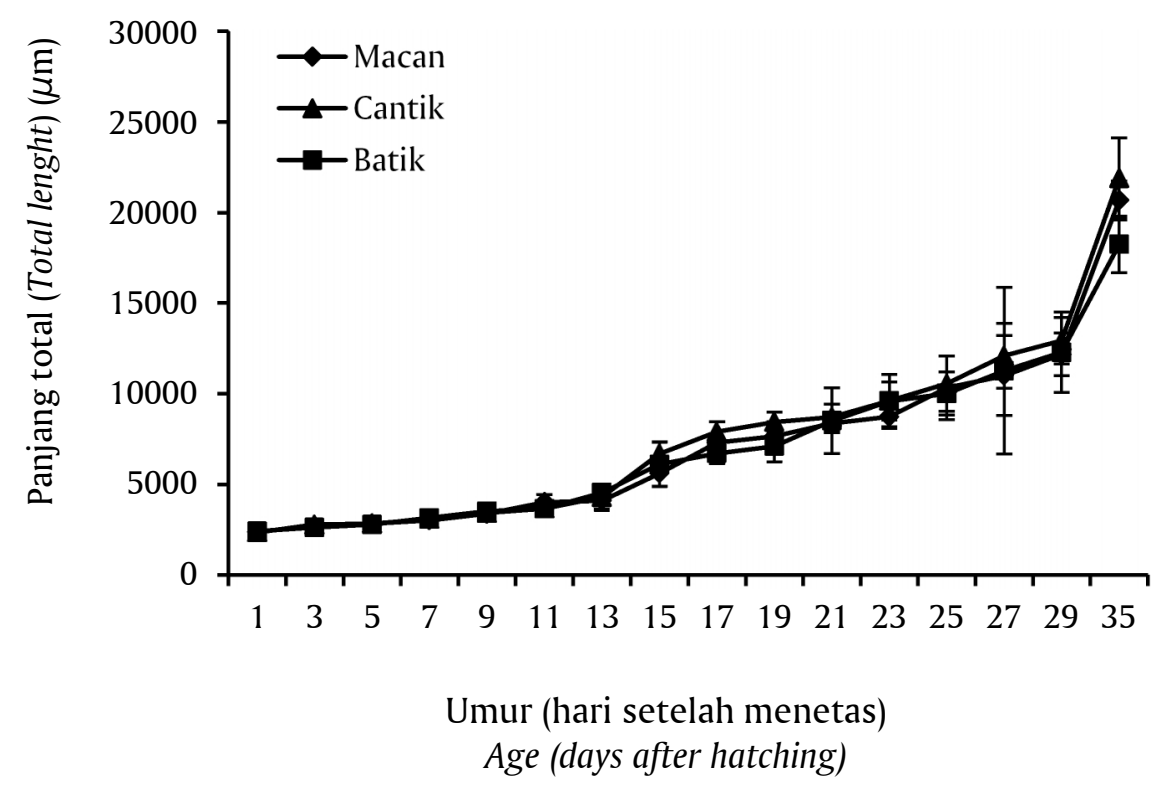

Gambar 3. Pertumbuhan panjang total larva kerapu hibrid cantik, macan, dan batik selama pemeliharaan

Figure 3. Growth in total length of hybrid grouper, tiger, and camouflage grouper larvae during rearing periods 

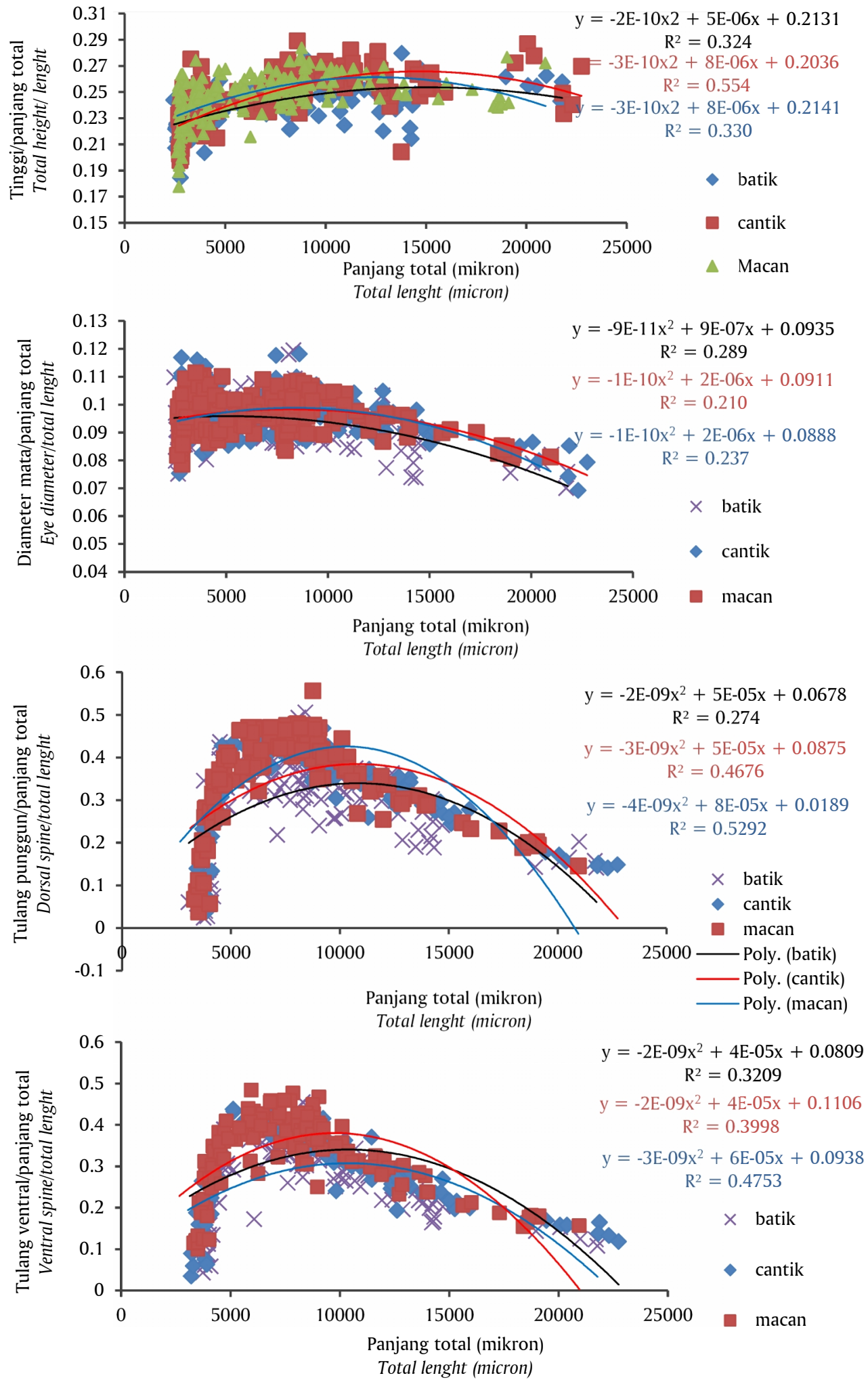

Gambar 4. Nilai rasio karakter morfologi larva kerapu dibandingkan dengan panjang total larva A) tinggi badan larva: panjang total; B) diameter mata: panjang total; C) duri sirip dorsal: panjang total; dan d) duri sirip ventral: panjang total

Figure 4. Ratio value of morphological characters of larvae compared with the total length of the larvae A) larvae height: the total length; B) eye diameter: total length; $C$ ) dorsal fin spine: total length; and d) ventral fin spine: total length 
cantik umur 35 hari sebesar $21.902 \pm 2.218 \mu \mathrm{m}$, kerapu macan $20.676 \pm 1.065 \mu \mathrm{m}$, dan kerapu batik $18.245 \pm 1.564 \mu \mathrm{m}$.

Nilai rasio beberapa karakter morfologi larva dibandingkan dengan panjang total larva tertera pada Gambar 4. Nilai rasio beberapa karakter morfologi yang diamati, memiliki pola yang serupa antara ikan kerapu batik, hibrida cantik, dan macan. Nilai rasio tinggi badan : panjang total ikan kerapu batik berkisar antara 0,18-0,28; ikan kerapu hibrid cantik 0,20-0,29 dan kerapu macan 0,18-0,28. Sementara nilai rasio diameter mata ikan kerapu batik berkisar antara 0,070,12 ; sedangkan pada ikan kerapu cantik dan macan masing-masing sebesar 0,07-0,12 dan 0,08-0,11. Nilai rasio panjang duri sirip dorsal : panjang total ikan kerapu batik berkisar antara 0,02-0,51; kerapu cantik 0,04-0,48 dan kerapu macan 0,04-0,56. Nilai rasio duri sirip ventral : panjang total ikan kerapu batik berkisar antara 0,04-0,45; kerapu cantik 0,03-0,44 dan kerapu macan $0,10-0,48$.

Hasil korelasi karakter morfologi antara kerapu batik, hibrid cantik, dan macan tersebut disajikan pada Tabel 3. Hasil analisis nilai korelasi menunjukkan bahwa larva kerapu cantik cenderung memiliki kemiripan dengan kerapu macan (99,9\%); dibandingkan antara kerapu cantik dengan batik $(98,1 \%)$. Namun demikian, cukup sulit untuk membedakan larva dari ketiga jenis kerapu tersebut, karena memiliki perbedaan nilai korelasi yang rendah.

Hasil pengamatan terhadap jumlah akhir, sintasan (survival rate/SR), dan umur larva pada saat pemanenan pada kerapu macan, cantik, dan batik ditunjukkan pada Tabel 4. Sintasan larva pada ketiga jenis kerapu saat panen menunjukkan perbedaan. Nilai sintasan tertinggi terdapat pada larva ikan kerapu cantik yaitu 6,24\% (3.975 ekor), sedangkan pada kerapu macan sebesar 0,78\% (720 ekor), dan sintasan terkecil pada kerapu batik 0,19\% (164 ekor). Larva kerapu hibrida cantik dan kerapu batik dipanen terlebih dahulu yaitu pada umur 37 hari dan selanjutnya kerapu macan pada umur 41 hari. Hal ini dilakukan karena larva kerapu hibrida cantik dan batik telah menjadi benih secara sempurna dan siap dipanen lebih awal pada umur 37 hari dibandingkan dengan kerapu macan yang baru berubah menjadi benih pada umur 41 hari.

\section{Pemeliharaan Benih Kerapu Hibrida Cantik dan Benih Kerapu Non-Hibrid (Batik dan Macan) Secara Komunal}

Hasil pengamatan selama empat bulan pemeliharan larva secara komunal hingga benih dari ketiga jenis kerapu, yaitu kerapu hibrida cantik dan non-hibrid

Tabel 3. Nilai korelasi karakter morfologi larva ikan kerapu batik, hibrid cantik, dan macan

Table 3. Correlation value of morphological characters of camouflage, hybrid cantik, and tiger grouper larvae

\begin{tabular}{lccc}
\hline & $\begin{array}{c}\text { Batik } \\
\text { Camouflage grouper }\end{array}$ & $\begin{array}{c}\text { Cantik } \\
\text { Hybrid grouper }\end{array}$ & $\begin{array}{c}\text { Macan } \\
\text { Tiger grouper }\end{array}$ \\
\hline Batik (Camouflage grouper) & 1 & & \\
Cantik (Hybrid grouper) & 0.981 & 1 & 1 \\
Macan (Tiger grouper) & 0.977 & $\mathbf{0 . 9 9 9}$ & 1 \\
\hline
\end{tabular}

Tabel 4. Sintasan dan umur larva saat panen ikan kerapu batik, cantik, dan macan

Table 4. Survival rate (SR), and larvae age of harvest of camouflage, hybrid cantik, and tiger grouper larvae

\begin{tabular}{lcccc}
\hline $\begin{array}{c}\text { Jenis kerapu } \\
\text { Species of Grouper }\end{array}$ & $\begin{array}{c}\text { Jumlah awal (ekor) } \\
\text { Initial number of larvae (fry) }\end{array}$ & $\begin{array}{c}\text { Jumlah akhir (ekor) } \\
\text { End number of larvae (fry) }\end{array}$ & $\begin{array}{c}\text { Sintasan } \\
\text { Survival rate (\%) }\end{array}$ & $\begin{array}{c}\text { Umur panen (hari) } \\
\text { Age harvest (days) }\end{array}$ \\
\hline $\begin{array}{l}\text { Kerapu macan } \\
\text { Tiger grouper } \\
\begin{array}{l}\text { Kerapu cantik } \\
\text { Hybrid grouper }\end{array}\end{array}$ & 92.365 & 720 & 0.78 & 41 \\
$\begin{array}{l}\text { Kerapu batik } \\
\text { Camouflage grouper }\end{array}$ & 63.700 & 3.975 & 6.24 & 37 \\
\hline
\end{tabular}



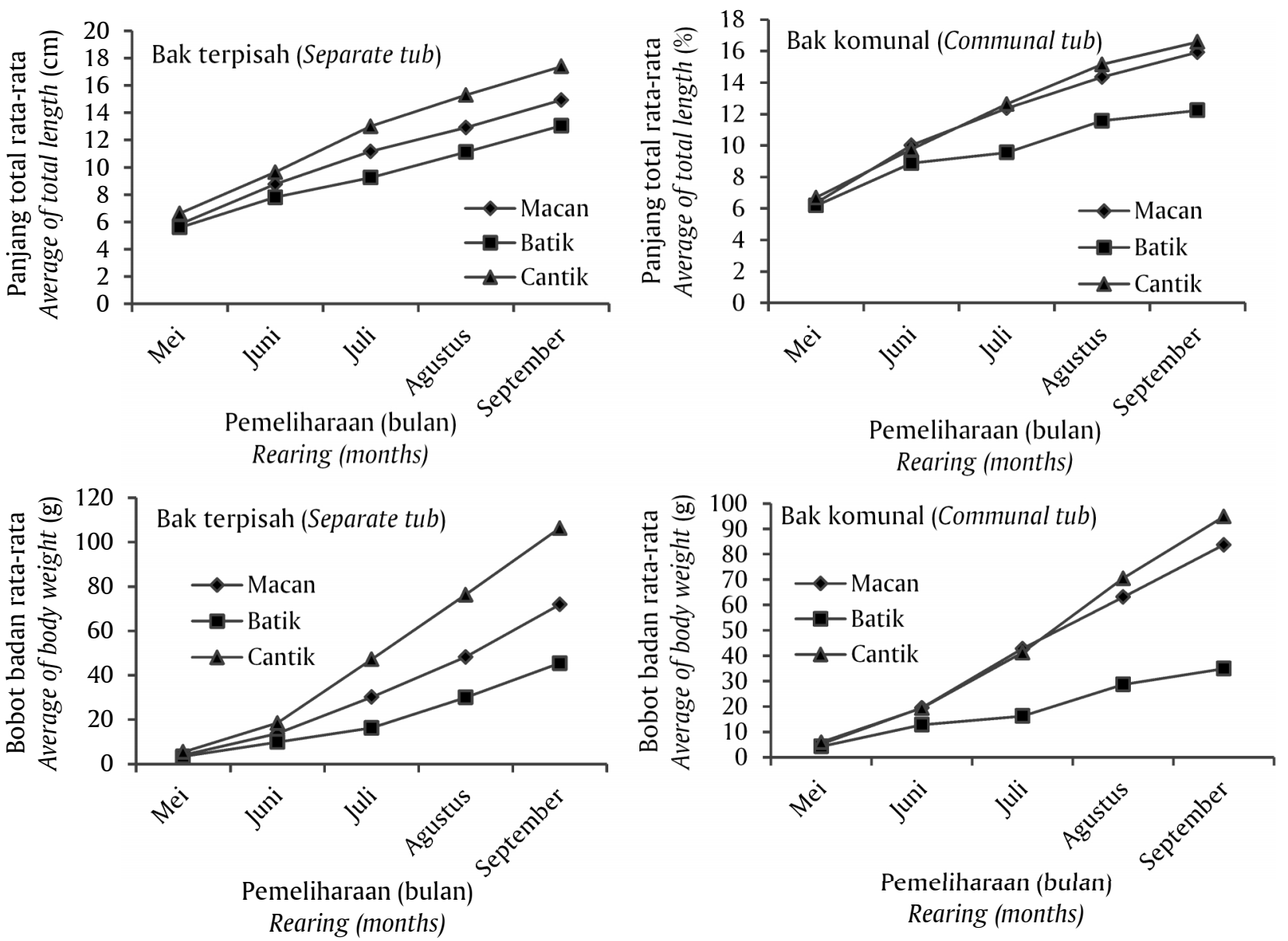

Gambar 5. Pertumbuhan panjang dan bobot benih kerapu hibrid cantik dan non-hibrid (batik dan macan) yang dipelihara terpisah dan secara komunal

Figure 5. Growth in total length and body weight of hybrid cantik and non hybrid grouper fry (camouflage and tiger grouper) reared independently and communally

(batik dan macan) diperoleh data pertumbuhan panjang dan bobot benih seperti dijelaskan pada Gambar 5. Ikan kerapu hibrida cantik memiliki pertumbuhan panjang dan bobot yang lebih baik dibandingkan kedua induk pembentuknya, baik yang dipelihara secara komunal maupun terpisah. Benih ikan kerapu batik memiliki pertumbuhan panjang dan bobot terkecil dibandingkan benih hibrida cantik dan benih kerapu macan.

Hasil pengamatan terhadap sintasan benih pada akhir pemeliharaan pada kerapu hibrida cantik dan nonhibrida yang dipelihara secara komunal dan terpisah disajikan pada Gambar 6. Sintasan ikan kerapu hibrida cantik mempunyai nilai yang paling besar dibandingkan non-hibrida, baik yang dipelihara secara komunal $(80,00 \%)$ maupun terpisah $(93,33 \%)$. Pemeliharaan benih ikan kerapu macan baik secara komunal $(72,00 \%)$ dan terpisah $(73,33 \%)$ tidak menunjukkan nilai sintasan yang berbeda. Sementara, pada sintasan benih ikan kerapu batik, mempunyai nilai sintasan lebih tinggi pada pemeliharaan secara terpisah $(81,33 \%)$ dibandingkan komunal $(24,00 \%)$. Pada pemeliharaan secara komunal, sintasan tertinggi pada ikan kerapu hibrida cantik $(80,00 \%)$ dan terendah adalah ikan kerapu batik $(72,00 \%)$. Hal ini menunjukkan bahwa ikan kerapu cantik mampu bersaing secara lebih baik dibandingkan dengan ikan kerapu asalnya yaitu kerapu macan dan kerapu batik. Rendahnya nilai sintasan ikan kerapu batik baik yang dipelihara secara terpisah maupun komunal menunjukkan pemeliharaan ikan kerapu batik lebih sulit dibanding kerapu lainnya. Hal ini terjadi karena ikan kerapu batik respons terhadap pakan lebih rendah dan tidak agresif seperti ikan kerapu yang lain.

Pengamatan meristik benih ikan kerapu hibrid cantik, macan, dan batik dijelaskan pada Tabel 5 yang meliputi jumlah tulang keras dan lunak pada sirip dorsal (punggung), ventral (perut), kaudal (ekor), anal (belakang), dan pektoral (dada). Karakter meristik ikan 


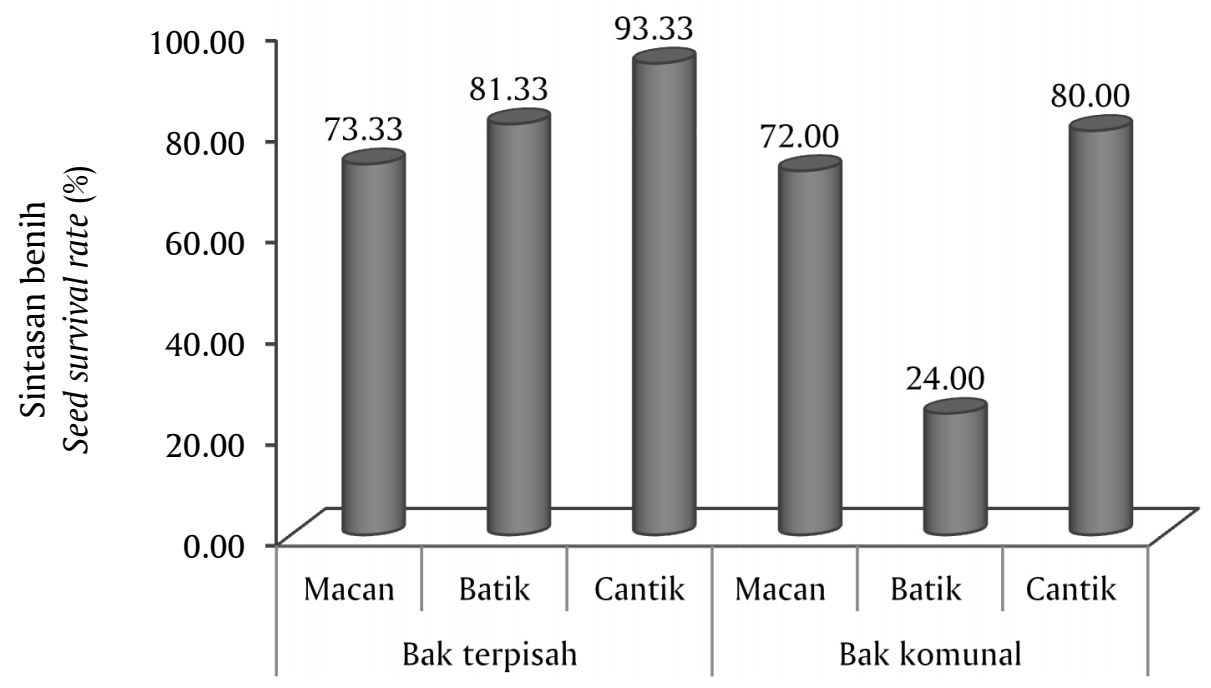

Gambar 6. Sintasan benih ikan kerapu cantik, macan, dan batik yang dipelihara secara terpisah dan komunal selama empat bulan pemeliharaan

Figure 6. Survival rate of hybrid cantik, tiger, and camouflage grouper that reared separately and communally four months rearing period

kerapu cantik memiliki banyak persamaan terhadap spesies induknya baik macan maupun batik pada semua jenis siripnya.

Hasil pengamatan terhadap ukuran morfometrik benih ikan kerapu cantik, macan dan batik disajikan pada Tabel 6. Nilai semua karakter morfometrik ikan kerapu cantik lebih besar dibandingkan kerapu macan dan batik karena mempunyai ukuran yang paling besar walaupun memiliki umur yang sama.

Karakter morfologi dibandingkan dengan panjang total untuk dianalisis korelasinya antara ikan kerapu hibrid cantik dengan spesies asalnya (macan dan batik) seperti tertera pada Tabel 7. Nilai korelasi secara keseluruhan antar karakter morfometrik pada kerapu hibrida cantik menunjukkan nilai kemiripan yang lebih tinggi terhadap ikan kerapu macan $(99,68 \%)$ seperti ditunjukkan pada Tabel 8. Namun demikian, ikan kerapu cantik juga memiliki kemiripan dengan kerapu batik yang ditunjukkan dengan nilai korelasi yang sedikit lebih kecil $(99,62 \%)$ dan perlu ketelitian untuk membedakan ketiga jenis kerapu tersebut.

\section{Karakter Genotipe Benih Ikan Kerapu Hibrida Cantik, dan Non-Hibrid (Kerapu Macan dan Batik)}

Hasil analisis mikrosatelit menggambarkan keragaman genetik populasi benih kerapu hibrida cantik dan non-hibrida (macan dan cantik) disajikan pada Tabel 9. Jumlah alel yang teramati pada lokus EM-07 sebanyak dua alel untuk semua benih ikan kerapu, sedangkan pada lokus EM-08 sebanyak tiga

Tabel 5. Karakter meristik benih ikan kerapu hibrid cantik, macan, dan batik

Tabel 5. Meristic character of hybrid cantik, tiger, and camouflage grouper fries

\begin{tabular}{lccc}
\hline Sirip (Fin) & $\begin{array}{c}\text { Kerapu macan } \\
\text { Tiger grouper }\end{array}$ & $\begin{array}{c}\text { Kerapu cantik } \\
\text { Hybrid grouper }\end{array}$ & $\begin{array}{c}\text { Kerapu batik } \\
\text { Camouflage grouper }\end{array}$ \\
\hline Dorsal & $\mathrm{X}-\mathrm{XI}, 13-15$ & $\mathrm{X}-\mathrm{XII}, 13-17$ & $\mathrm{XI}, 13-17$ \\
Ventral & $\mathrm{I}, 4-5$ & $\mathrm{I}, 4-6$ & $\mathrm{I}, 4-5$ \\
Kaudal & $16-18$ & $13-17$ & $16-18$ \\
Anal & $\mathrm{III}, 7-9$ & $\mathrm{III}, 7-10$ & $\mathrm{III}, 8-11$ \\
Pektoral & $16-18$ & $16-18$ & $14-18$ \\
\hline
\end{tabular}

Keterangan (Note): Angka romawi menunjukkan jumlah tulang keras 
Tabel 6. Karakter morfometrik benih ikan kerapu cantik, macan, dan batik

Table 6. Morphometric characters of hybrid cantik, tiger, and camouflage groupers fries

\begin{tabular}{|c|c|c|c|}
\hline $\begin{array}{l}\text { Karakter morfometrik } \\
\text { Morphometric characters }\end{array}$ & $\begin{array}{c}\text { Kerapu macan } \\
\text { Tiger grouper }\end{array}$ & $\begin{array}{l}\text { Kerapu cantik } \\
\text { Hybrid grouper }\end{array}$ & $\begin{array}{c}\text { Kerapu batik } \\
\text { Camouflage grouper }\end{array}$ \\
\hline Panjang total (PT) (Total length) $(\mathrm{cm})$ & $19.65 \pm 1.33$ & $22.35 \pm 0.82$ & $15.82 \pm 0.69$ \\
\hline $\begin{array}{l}\text { Panjang standar (PS } \\
\text { Standard length }(\mathrm{cm})\end{array}$ & $16.03 \pm 1.26$ & $18.25 \pm 0.79$ & $12.75 \pm 0.59$ \\
\hline $\begin{array}{l}\text { Diameter mata }(\mathrm{DM}) \\
\text { Eye diameter }(\mathrm{cm})\end{array}$ & $0.82 \pm 0.15$ & $0.98 \pm 0.09$ & $0.80 \pm 0.13$ \\
\hline $\begin{array}{l}\text { Tinggi badan (TB) } \\
\text { Body height }(\mathrm{cm})\end{array}$ & $5.9 \pm 0.5$ & $6.2 \pm 0.3$ & $4.3 \pm 0.30$ \\
\hline $\begin{array}{l}\text { Panjang kepala (PK) } \\
\text { Head length }(\mathrm{cm})\end{array}$ & $5.53 \pm 0.70$ & $6.75 \pm 0.54$ & $4.73 \pm 0.64$ \\
\hline $\begin{array}{l}\text { Panjang dorsal (PD) } \\
\text { Dorsal length }(\mathrm{cm})\end{array}$ & $9.34 \pm 0.64$ & $10.25 \pm 0.98$ & $7.61 \pm 0.59$ \\
\hline $\begin{array}{l}\text { Tinggi dorsal (TD) } \\
\text { Dorsal height (cm) }\end{array}$ & $1.36 \pm 0.2$ & $1.47 \pm 0.19$ & $1.24 \pm 0.14$ \\
\hline $\begin{array}{l}\text { Panjang pectoral (PP) } \\
\text { Pectoral length }(\mathrm{cm})\end{array}$ & $3.04 \pm 1.34$ & $3.41 \pm 0.31$ & $2.74 \pm 0.16$ \\
\hline $\begin{array}{l}\text { Tinggi pectoral (TP) } \\
\text { Pectoral height }(\mathrm{cm})\end{array}$ & $3.1 \pm 1.13$ & $4.04 \pm 0.27$ & $2.72 \pm 0.22$ \\
\hline $\begin{array}{l}\text { Panjang anal }(\mathrm{PA}) \\
\text { Anal length }(\mathrm{cm})\end{array}$ & $2.71 \pm 0.24$ & $3.26 \pm 0.27$ & $2.38 \pm 0.21$ \\
\hline $\begin{array}{l}\text { Tinggi anal }(\mathrm{TA}) \\
\text { Anal height }(\mathrm{cm})\end{array}$ & $1.37 \pm 0.21$ & $1.53 \pm 0.16$ & $1.3 \pm 0.12$ \\
\hline $\begin{array}{l}\text { Tinggi ventral (TV) } \\
\text { Ventral height (cm) }\end{array}$ & $2.53 \pm 0.45$ & $2.99 \pm 0.35$ & $2.30 \pm 0.22$ \\
\hline $\begin{array}{l}\text { Tinggi batang ekor }(\mathrm{TBE}) \\
\text { Caudal peduncle height }(\mathrm{cm})\end{array}$ & $2.27 \pm 0.18$ & $2.37 \pm 0.13$ & $1.55 \pm 0.16$ \\
\hline $\begin{array}{l}\text { Tinggi caudal (TC) } \\
\text { Caudal height }(\mathrm{cm})\end{array}$ & $4.24 \pm 0.58$ & $5.08 \pm 0.47$ & $3.02 \pm 0.32$ \\
\hline $\begin{array}{l}\text { Lebar badan }(\mathrm{LB}) \\
\text { Body wide }(\mathrm{cm})\end{array}$ & $3.34 \pm 0.35$ & $3.57 \pm 0.21$ & $2.26 \pm 0.14$ \\
\hline
\end{tabular}

alel teramati untuk benih ikan kerapu hibrida cantik dan batik dan hanya satu alel teramati pada ikan kerapu macan. Banyaknya jumlah alel yang teramati pada benih kerapu hibrida diduga berasal dari induk kerapu batik. Benih Ikan kerapu hibrida cantik mempunyai nilai PIC lebih tinggi $(0,375-0,466)$ dibandingkan benih ikan kerapu macan $(0,000-0,375)$ dan batik $(0,164-0,466)$. Heterozigositas benih ikan kerapu hibrida $(0,556$ $0,600)$ lebih tinggi dibandingkan ikan kerapu macan $(0,000-0,556)$ dan batik $(0,200-0,600)$.

Pola pewarisan alel ikan kerapu hibrida cantik dari kedua induknya tersaji pada Tabel 10 . Hasil analisis menunjukkan bahwa alel-alel ikan benih kerapu hibrida cantik yang dianalisis merupakan perpaduan alel-alel yang diwariskan dari kedua induknya baik pada lokus EM-07 maupun lokus EM-08. Pada lokus EM-07, benih ikan kerapu cantik mempunyai alel AC yang merupakan perpaduan dari induk jantan kerapu batik (AA) dan betina kerapu macan (BC). Sedangkan pada lokus EM08 , benih ikan kerapu cantik mempunyai alel $A D, B D$, dan DD yang merupakan perpaduan dari induk jantan batik $(\mathrm{AB})$ dan betina kerapu macan (DD).

\section{BAHASAN}

Hasil persilangan antara induk betina kerapu macan dengan jantan kerapu batik menghasilkan benih ikan 
Tabel 7. Perbandingan karakter morfometrik dan pada ikan kerapu macan, batik, dan cantik

Table 7. The morphometric character ratio of tiger, camouflage, and hybrid cantik, groupers fries

\begin{tabular}{lccc}
\hline $\begin{array}{c}\text { Karakter morfometrik } \\
\text { Morphometric characters }\end{array}$ & $\begin{array}{c}\text { Macan } \\
\text { Tiger grouper }\end{array}$ & $\begin{array}{c}\text { Batik } \\
\text { Camouflage grouper }\end{array}$ & $\begin{array}{c}\text { Cantik } \\
\text { Hybrid grouper }\end{array}$ \\
\hline PS : PT & 0.815 & 0.806 & 0.816 \\
DM : PT & 0.042 & 0.051 & 0.044 \\
TB : PT & 0.301 & 0.271 & 0.277 \\
PK : PT & 0.282 & 0.298 & 0.302 \\
PD : PT & 0.476 & 0.481 & 0.458 \\
TD : PT & 0.069 & 0.078 & 0.066 \\
PP : PT & 0.153 & 0.173 & 0.153 \\
TP : PT & 0.157 & 0.172 & 0.181 \\
PA : PT & 0.138 & 0.150 & 0.146 \\
TA : PT & 0.070 & 0.082 & 0.068 \\
TV : PT & 0.129 & 0.145 & 0.134 \\
TBE : PT & 0.116 & 0.098 & 0.106 \\
TC : PT & 0.216 & 0.191 & 0.227 \\
LB : PT & 0.170 & 0.143 & 0.160 \\
\hline
\end{tabular}

Tabel 8. Matrik korelasi seluruh karakter morfometrik ikan kerapu cantik, batik, dan macan

Table 8. Correlation matrix of all morphometric character of hybrid cantik, tiger, and camouflage groupers seed

\begin{tabular}{lccc}
\hline & $\begin{array}{c}\text { Macan } \\
\text { Tiger grouper }\end{array}$ & $\begin{array}{c}\text { Batik } \\
\text { Camouflage grouper }\end{array}$ & $\begin{array}{c}\text { Cantik } \\
\text { Hybrid grouper }\end{array}$ \\
\hline $\begin{array}{l}\text { Macan } \\
\text { Tiger grouper }\end{array}$ & 1 & & \\
$\begin{array}{l}\text { Cantik } \\
\text { Hybrid grouper }\end{array}$ & 0.996 & 1 & \\
$\begin{array}{l}\text { Batik } \\
\text { Camouflage grouper }\end{array}$ & 0.995 & 0.996 & 1 \\
\hline
\end{tabular}

Tabel 9. Nilai keragaman genetik ikan kerapu hibrid cantik, macan, dan batik Table 9. Genetic variation value of hybrid cantik, tiger, and camouflage grouper

\begin{tabular}{|c|c|c|c|c|c|c|}
\hline \multirow{2}{*}{$\begin{array}{c}\text { Kerapu } \\
\text { Grouper spesies }\end{array}$} & \multicolumn{2}{|c|}{$\begin{array}{c}\text { Jumlah alel } \\
\text { Number of alleles }\end{array}$} & \multicolumn{2}{|c|}{$\begin{array}{c}\text { PIC } \\
\text { (Polymorphisme information } \\
\text { conformation) }\end{array}$} & \multicolumn{2}{|c|}{$\begin{array}{c}\text { Heterozigositas } \\
\text { Heterozigocity }\end{array}$} \\
\hline & $\begin{array}{c}\text { Lokus EM-07 } \\
\text { Loci EM-07 }\end{array}$ & $\begin{array}{c}\text { Lokus EM-08 } \\
\text { Loci EM-08 }\end{array}$ & $\begin{array}{c}\text { Lokus EM-07 } \\
\text { Loci EM-07 }\end{array}$ & $\begin{array}{c}\text { Lokus EM-08 } \\
\text { Loci EM-08 }\end{array}$ & $\begin{array}{c}\text { Lokus EM-07 } \\
\text { Loci EM-07 }\end{array}$ & $\begin{array}{c}\text { Lokus EM-08 } \\
\text { Loci EM-08 }\end{array}$ \\
\hline $\begin{array}{l}\text { Kerapu cantik } \\
\text { Hybrid grouper }\end{array}$ & 2 & 3 & 0.375 & 0.466 & 0.556 & 0.600 \\
\hline $\begin{array}{l}\text { Kerapu batik } \\
\text { Camouflage grouper }\end{array}$ & 2 & 3 & 0.164 & 0.466 & 0.200 & 0.600 \\
\hline $\begin{array}{l}\text { Kerapu macan } \\
\text { Tiger grouper }\end{array}$ & 2 & 1 & 0.375 & 0.000 & 0.556 & 0.000 \\
\hline
\end{tabular}


Tabel 10. Pola pewarisan alel ikan kerapu cantik dari induk asalnya

Table 10. Allele inheritance pattern of cantik grouper from the broodstock

\begin{tabular}{lcc}
\hline & $\begin{array}{c}\text { Lokus EM-07 } \\
\text { Loci EM-07 }\end{array}$ & $\begin{array}{c}\text { Lokus EM-08 } \\
\text { Loci EM-08 }\end{array}$ \\
\hline $\begin{array}{l}\text { Induk jantan kerapu batik } \\
\text { Male parent grouper batik }\end{array}$ & $\mathrm{AA}$ & $\mathrm{AB}$ \\
$\begin{array}{l}\text { Induk betina kerapu macan } \\
\text { Female parent grouper batik } \\
\text { Benih kerapu cantik 1 }\end{array}$ & $\mathrm{BC}$ & $\mathrm{DD}$ \\
$\begin{array}{l}\text { Grouper fingerlings cantik 1 } \\
\text { Benih kerapu cantik 2 } \\
\text { Grouper fingerlings cantik 2 } \\
\text { Benih kerapu cantik 3 }\end{array}$ & AC & BD \\
$\begin{array}{l}\text { Grouper fingerlings cantik 3 } \\
\text { Benih kerapu cantik 4 } \\
\text { Grouper fingerlings cantik 4 } \\
\text { Benih kerapu cantik 5 } \\
\text { Grouper fingerlings cantik 5 }\end{array}$ & AC & AD \\
\hline
\end{tabular}

kerapu hibrida cantik. Telur dan sperma yang digunakan merupakan telur yang embrio dan sperma yang berkualitas baik dengan motilitas aktif, sehingga dihasilkan telur fertil ikan kerapu hibrida. Telur hibrida yang dihasilkan menunjukkan kualitas yang lebih baik, yaitu ditunjukkan dengan diameter telur dan butir minyak lebih besar dibandingkan telur kerapu macan dan batik. Namun demikian, daya tetas telur ikan kerapu cantik masih lebih rendah daripada ikan kerapu macan, tetapi masih lebih tinggi dibandingkan dengan ikan kerapu batik.

Pertumbuhan larva ikan kerapu hibrid cantik yang diamati dari pertambahan panjang total menunjukkan nilai yang lebih baik dibandingkan dengan larva ikan kerapu macan dan cantik. Hal ini dibuktikan dengan metamorfosis larva kerapu cantik yang lebih cepat sehingga siap dipanen dengan waktu lebih awal. Selain itu, sintasan larva ikan kerapu hibrid cantik pada saat dipanen juga lebih tinggi $(6,24 \%)$ dibandingkan dengan larva ikan kerapu macan dan kerapu batik. James et al. (1999) menyatakan bahwa hasil hibridisasi antara ikan kerapu macan dan kerapu batik menunjukkan pertumbuhan yang lebih baik dibandingkan tetuanya.

Hasil yang diperoleh pada beberapa karakter morfologi yang diamati memiliki pola yang serupa antara larva ikan kerapu hibrid cantik, macan, dan batik, sehingga cukup sulit membedakan larvanya. Namun larva ikan kerapu cantik cenderung memiliki kemiripan dengan larva kerapu macan sesuai dengan analisis korelasi (Tabel 3).

Hasil pemeliharaan benih kerapu hibrida cantik, macan, dan batik menunjukkan pertumbuhan dan sintasan benih kerapu cantik lebih baik dibandingkan dengan ikan kerapu macan dan batik pada pemeliharaan baik secara terpisah maupun komunal. Sugama et al. (2014) menyatakan bahwa ikan kerapu hibrida mempunyai tingkat fluktuasi asimetri yang lebih rendah dibandingkan dengan ikan kerapu macan dan batik sehingga mempunyai stabilitas perkembangan yang lebih baik dan berkaitan erat dengan pertumbuhan ikan. Hal ini sesuai dengan salah satu tujuan hibridisasi yaitu untuk meningkatkan laju pertumbuhan (Bartley et al., 2001).

Hasil pengamatan meristik dan morfometrik benih ikan kerapu hibrida cantik memiliki banyak kemiripan dengan kedua induk pembentukannya. Walaupun hasil analisis korelasi menunjukkan bahwa benih kerapu hibrida cantik cenderung memiliki kemiripan dengan kerapu macan. Untuk membedakan benih kerapu hibrida cantik, macan, dan batik relatif sulit, mengingat di antara ketiga jenis kerapu tersebut memiliki nilai korelasi yang tinggi $(0,995-0,996)$ (Tabel 8).

Berdasarkan hasil analisis menggunakan penanda mikrosatelit, ikan kerapu hibrida cantik memiliki keragaman genetik yang lebih tinggi dibandingkan 
dengan ikan kerapu macan dan batik. Ikan kerapu cantik mempunyai alel-alel yang merupakan perpaduan alel yang diwariskan dari induknya. Hal ini sesuai dengan analisis morfologi dan meristiknya, di mana benih kerapu cantik mendapatkan sifat-sifat dari kedua induknya sehingga secara morfologi mempunyai kemiripan dengan kedua induknya. Ikan kerapu cantik merupakan hasil persilangan antara betina ikan kerapu macan dengan jantan kerapu batik yang membuktikan bahwa persilangan dapat meningkatkan nilai keragaman genetik. Sugama et al. (2014) menyatakan bahwa heterozigositas tinggi diduga dapat menurunkan fluktuasi asimetri, sehingga ikan kerapu hibrida cantik memiliki pertumbuhan yang lebih baik dibandingkan dari benih dari kedua induk pembentuknya. Nilai heterosis benih kerapu hibrida cantik tidak dapat dihitung karena tidak dihasilkan benih hibrida resiproknya akibat pemeliharaan larvanya yang cukup susah.

Dengan dikuasainya teknologi pemeliharaan larva dan memiliki pertumbuhan yang lebih baik dibandingkan kerapu macan dan kerapu batik, ikan kerapu hibrida cantik potensial untuk dibudidayakan sebagai spesies alternatif terutama di saat terjadi penurunan permintaan terhadap benih ikan kerapu bebek dan ikan kerapu macan.

\section{KESIMPULAN}

Hasil persilangan antara induk betina kerapu macan dan jantan kerapu batik menghasilkan ikan kerapu hibrida cantik yang mempunyai pertumbuhan larva dan benih, serta sintasan yang lebih baik dibandingkan dengan ikan kerapu macan dan batik. Ikan kerapu hibrida cantik cenderung memiliki kesamaan dengan ikan kerapu macan baik pada karakter morfometrik maupun meristik. Nilai heterozigositas ikan kerapu hibrida cantik lebih tinggi dan mempunyai alel-alel yang merupakan perpaduan yang diwariskan kedua induk asalnya.

\section{UCAPAN TERIMA KASIH}

Penelitian ini dibiayai dari anggaran DIPA Balai Besar Penelitian dan Pengembangan Budidaya Laut, Gondol tahun 2014. Terima kasih disampaikan kepada semua pihak yang telah membantu pelaksanaan penelitian ini terutama Katimin dan Iksan selaku teknisi serta dari CV Dewata Laut yaitu Bapak Nyoman Sawitra, Apri I. Supii, Gigih Setia Wibawa, dan David.

\section{DAFTAR ACUAN}

Bartley, D.M., Rana, K., \& Immink, A.J. (2001). The use of inter-specific hybrids in aquaculture and fisheries. Reviews in Fish Biology and Fisheries, 10, 325-337.

Chu, K.I.C., Shaleh, S.R.M., Akazawa, N., Oota, Y., \& Senoo, S. (2010). Egg and larval development of a new hybrid orange-spotted grouper Epinephelus coioides $\mathrm{x}$ giant grouper E. lanceolatus. Aquaculture Science, 58(1), 1-10.

Glamuzina, B., Kozul, V., Tutman, P., \& Skaramuc, B. (1999). Hybridization of mediterranean groupers: Epinephelus marginatus x E. aeneus and early development. Aquaculture Research, 30, 625-628.

Glamuzina, B., Glavic', N., Skaramuca, B., Kozcul, V., \& Tutman, P. (2001). Early development of the hybrid Epinephelus costae x E. marginatus. Aquaculture, 198, 55-61.

Frisch, J.A., \& Hobbs, J.P.A. (2007). In vitro hybridization of coral trouts, Plectropomus leopardus (Lacepe'de, 1802) and Plectropomus maculatus (Bloch, 1790): a preliminary investigation. Aquaculture Research, 38, 215-218.

James, C.M., Al-Thobaiti, S.A., Rasem, B.M., \& Carlos, M.H., (1999). Potensial of groper hybrid (Epinephelus fuscoguttatus $\mathrm{x}$ Epinephelus polyphekadion) for Aquaculture. Naga. The ICLARM Quareterly, 22(1), 19-23.

Kime, D.E., van Look, K.J.W., McAllister, B.G., Huyskens, G., Rurangwa, E., \& Ollevier, F. (2001). Computer-assisted sperm analysis (CASA) as a tool for monitoring sperm quality in fish. Comparative Biochemistry and Physiology, Part C 130, 425-433.

Kiriyakit, A., Gallardo, W.G., \& Bart, A.N. (2011). Successful hybridization of groupers (Epinephelus coioides $\mathrm{x}$ Epinephelus lanceolatus) using cryopreserved sperm. Aquaculture, 320, 106-112.

Sugama, K., Rimmer, M.A., Ismi, S., Koesharyani, I., Suwirya, K., Giri N.A., \& Alava, V.R. (2012). Hatchery management of tiger grouper (Epinephelus fuscoguttatus): a best-practice manual. ACIAR. Canberra, 66 pp.

Sugama, K., Muzaki, A., Permana, I G.N., \& Haryanti. (2014). Fluctuating asymmetri reflect the growth of hybrid grouper Epinephelus fuscoguttatus and Epinephelus polyphekadion. Indonesian Aquaculture Journal, 9(2), 97-103. 